\title{
The Relationship between Attention Levels and Class Participation of First-Year Students in Classroom Teaching Departments ${ }^{1}$
}

\author{
Adem Sezer \\ Assoc. Prof. Dr. Uşak University, Faculty of Education, Department of Primary \\ Education, Turkey,admsezer@hotmail.com \\ Yusuf İnel \\ Asst. Prof. Dr., Uşak University, Faculty of Education, Department of Primary \\ Education, Division of Social Studies Education, Turkey, ysf.inel@gmail.com
}

\author{
Ahmet Çağdaş Seçkin \\ Lecturer, Uşak University, Vocational School, Electronic Technology Programme, \\ Turkey,cagdaseckin@gmail.com
}

\section{Ufuk Uluçınar}

Res. Ast., Uşak University, Faculty of Education, Department of Educational Sciences, Division of Curriculum and Instruction, Turkey, ufuk.ulucinar@gmail.com

\begin{abstract}
This study aimed to detect any relationship that may exist between classroom teacher candidates' class participation and their attention levels. The research method was a convergent parallel design, mixing quantitative and qualitative research techniques, and the study group was composed of 21 freshmen studying in the Classroom Teaching Department at Uşak University, Faculty of Education, in the autumn term of the 2014-2015 academic year. As a data collection instrument, NeuroSky's Mindset EEG equipment was used to detect the students' attention levels, with video-recording being used to detect their class participation. The data obtained were analysed using the PYTHON and MATLAB package programs. The findings showed that, according to the eSense metric, students' level attention was averagely natural (43) as it was stated. The study concluded that there existed a moderate, positive correlation between students' attention levels and class participation.
\end{abstract}

Key Words: attention level, class participation, NeuroSky's MindWave Mindset (EEG), classroom teacher candidates

\footnotetext{
${ }^{1}$ This study was supported by Uşak University Scientific Research Unit in the context of 2013/SOSB004 project no.
}

Citation: Sezer, A., İnel, Y., Seçkin, A. C. \& Uluçınar, U. (2017). The Relationship between Attention Levels and Class Participation of First-Year Students in Classroom Teaching Departments. International Journal of Instruction, 10(2), 55-68. https://doi.org/10.12973/iji.2017.1024a 


\section{INTRODUCTION}

The changes that occur in individuals' and societies' needs and expectations add variety to the information that the individual must gather on a daily basis and make learning a necessity as well as an obligation, thereby increasing its importance. This in turn highlights the need in a general sense to study learning, which is defined as a permanent change in behaviour (Bilen, 2006), and the many interacting factors that affect it (McNamara, 1994) from all possible aspects. Even though these factors are basically classified in different ways according to their features, almost all theoretical classification refers to class participation and students' attention levels, which were the variables in this study (Bacanlı, 2002; Tuncer, Bal, Özüt, \& Köse, 2012).

Relevant studies underline that class participation is crucial in that it raises the quality of learning, and also point out that participating students are more open and eager to learn (Ames, 1992; Eryılmaz, 2014; Eryılmaz and Aypay, 2011; Pintrich \& De Groot, 1990). Besides, a similar amount of importance is also attached to students' attention levels, with attention in the classroom even being described as a prerequisite of learning (Driscoll, 2012; Massora \& Cowan, 1993; Morgan, 2011; Schunk, 2008; Senemoğlu, 2005). In addition to their significance for learning, class participation and attention levels are understood to affect student motivation, as a highly motivated student displays high levels of attention and class participation (Fidan, 1996; Schunk, 2008). Furthermore, all this implies a relationship between class participation and attention levels.

Based on this assumption, the relevant literature was reviewed, and it was observed that studies of class participation were in general about students' motivation levels, selforganizational skills, and learning strategies (Pintrich and De Groot, 1990; Bomia, Beluzo, Demeester, Elander, Johnson, and Sheldon, 1997; Kayan-Fadlelmula, 2010; Eryılmaz and Aypay, 2011; Aypay and Eryılmaz, 2011; Eryılmaz, 2014), and that research about attention tended to focus mainly on hyperactive children as well as on the use of materials, measuring attention, and improving attention skills (Price, Crawford, Tottle, and Maunula, 2006; Stewart, Rule, and Giardona, 2007; Barkley, 2008; Demirova, 2008; Schmidt and Vandewater, 2008; Corkum, McGonnell and Schachar, 2010; Rabiner, Murray, Skinner, and Malone, 2010; Tahiroğlu, Çelik, Seydaoğlu, Uzel, and Altunbaş, 2010; İnel, 2014; Sezer, İnel, Seçkin, and Uluçınar, 2015).

To the best of the researcher's, research that has tested the link between class participation and attention levels was still limited in the literature review, which reinforces the purpose and originality of this research. Furthermore, the detection and analysis of students' attention levels when participating in real classroom settings increase the ecological validity of the study.

\section{Research Purpose}

This study aimed to detect the link between class participation and attention levels in the first-year classroom teaching students at Uşak University, Faculty of Education. In the light of this goal, answers were sought to the following research questions: 
1. What are the students' attention levels when participating in the class?

Is there a significant relationship between the students' attention levels during class participation and their class participation rates?

\section{METHOD}

The study design was a convergent parallel one, in line with triangulation in research methods. In convergent parallel design, qualitative and quantitative data are simultaneously collected but separately analysed (Creswell \& Plano Clark, 2014). In this study, the time series experimental design was used to collect the quantitative data, and instrumental observation was made to collect the qualitative data.

The time series experimental design, in which the measurement values repeated over 50 or more periods of time are used (Tabachnick and Fidell, 2015), detects the change over the given period in the effects of the independent variable on the dependent variable (Wiersma, 1985; Scott and Usher, 1999; Sümbüloğlu and Sümbüloğlu, 2007; Erkuş, 2011; Sönmez and Alacapınar, 2011; Büyüköztürk, Çakmak, Akgün, Karadeniz, and Demirel, 2012).

\section{Study Group}

Criterion sampling was used in the formation of the study group and the criteria were that the students were in their first year, taking the "General Geography" course, and voluntary participants. Along the lines of these criteria, 21 voluntary participants -10 male and 11 female - were selected from among the first-year students of classroom teaching in the Faculty of Education in the autumn term of the 2014-2015 academic year.

This article was derived from the project that was supported by the Scientific Research Unit of Uşak University, no. 2013/SOSB004. Before the project, approval was given by the ethics committe at the university. Moreover, students participating in the study were chosen voluntarily in the context of research ethics. Before the project began, we presented each participant with a written agreement explaining several dimensions of the study and requesting participant's acceptance to participate in the study based on their informed consent to do so (Neuman, 2009: 202).

\section{Data Collection Instruments}

NeuroSky's MindBuilder - EM (MB) - EEG equipment was used to collect the quantitative data of the study, with video-recording being used to ensure stimulus synchronization and to detect class participation rates.

Developed as a bio-sensor, NeuroSky's Mindset is an instrument serving to interpret the electrical activity that occurs in the detection of states of attention and relaxation in the brain. Designed as a simple headset, the instrument has a part attached to the participant's forehead, which serves as an electrode and allows the user to obtain brain signals from neural activity. The signals obtained are turned into numeric values between 0 and 100, and a data set is formed by reading the attention and meditation 
value. In this data, the Delta, Theta, Alpha, Beta, and Gamma brainwave values, together with the attention and meditation levels, are attributed significance (Crowley, Sliney, and Murphy, 2010; Sezer, İnel, Seçkin, and Uluçınar, 2015; MindWave User Guide, 2009; Salabun, 2014).

\section{Reliability of the Data Collection Instrument}

The study entitled "Assessing NeuroSky's Usability to Detect Attention Levels in an Assessment Exercise", which assesses the usability of NeuroSky's MindBuilder - EM (MB) equipment, concludes that the EEG data from the equipment present results parallel to students' attention levels (Rebolledo-Mendes, Dunwell, Martvnes-Miron, Vargas-Cerdan, de Freitas, Liarokapis, and Garcva-Gaona, 2009).

In their study of the reliability of NeuroSky's Mindset equipment in measuring participants' attention and meditation levels, Crowley, Sliney, Pitt and Murphy (2010) compare the data obtained by means of Stroop and Towers of Hanoi tests with the data yielded by NeuroSky's Mindset equipment, and conclude that NeuroSky's Mindset equipment is a reliable instrument for measuring attention and meditation levels.

In a similar vein, Sezer, İnel, Seçkin, and Uluçınar (2015) test the suitability of NeuroSky's Mindwave equipment for measuring attention levels, comparing the data yielded by the devices connected during the " $\mathrm{d} 2$ " attention test with the results of the "d2" attention test. Their findings suggest a moderately [Kendall $\tau$ (tau) 0.41 ] significant relationship between the data obtained from the " $\mathrm{d} 2$ " attention test and those yielded by the equipment. This finding demonstrates that the equipment is a valid and reliable instrument for measuring attention levels.

\section{Experimental Process}

In the beginning of the experimental process, the classroom seating positions were arranged A-shaped, to the extent that the physical conditions allowed, so that every student could easily see the instructor. Then seven NeuroSky's MindBuilder - EM (MB) devices were connected to each computer, with a total of 21 devices connected to three computers. The three video cameras previously installed in the classroom (one at the back - centre, one at the front - right, and one at the front - left) were simultaneously operated in the next phase.

The practice stage took 40 minutes and 9 questions were asked to students in the classroom by the lecturer at the end of the course. Students voluntarily responded to them. At the same time, students' attention levels were recorded via the NeuroSky's MindBuilder-EM (MB) devices.

9 open-ended questions involving the subject matters of the Physical Geography of Turkey were verbally asked to participants. These questions were designed around the level of synthesis in Bloom's taxonomy. In the study, we focused not only on whether students participated in the course, but also on the correctness of the responses received. The questions were directed orally to students. Therefore, the indices of item-difficulty in questions have been not calculated. The level of difficulty in the questions was 
constructed through expert opinion. In accordance with the purpose of this study, we looked at the relationship between students' attention levels and their participation in the courses.

\section{Data Analysis}

For the analysis of the signals obtained from the NeuroSky's MindBuilder - EM (MB) equipment, first the raw (not yet interpreted) digital signals were taken from the EEG device and recorded on a previously prepared database, with the signal, time, signal length, person, and electrode parameters being separately entered. Data loss occurred owing to students manually interfering with the device during the class - the data from seven such students were excluded from the analysis, which instead focused on the data from the remaining 14 students. The video recordings were viewed to detect the stimulus-time lengths of the data obtained, and the lengths (of class participation) were determined for each period detected. The Fourier transform signal processing method was used for the frequency study of the signals received from the EEG device in those moments. The data were then analysed by means of the PYTHON and MATLAB programs.

The eSense metric was used to interpret the data analysis results. In this metric, the attention and meditation levels are scaled between 1 and 100. The natural state, or the basis, falls between 40 and 60.60 to 80 is slightly high and 80 to 100 is very high. Likewise, 20 to 40 is slightly low and 0 to 20 is very low. The lower ends of the scale are found to appear in unexpected circumstances and in states of distraction and excitement (MindWave User Guide, 2009).

\section{FINDINGS}

\section{Findings about Research Question One}

The first research question in the study was "What are the students' attention levels when participating in the class?". In order to find answers to this question, the questions previously prepared by the instructor were put to the whole class, and answers were elicited on a voluntary basis. The students' attention level averages when answering the questions and the repeat participation figures were obtained, and the results are presented in Table 1. 
Table 1

Students' attention level averages during class participation and repeat participation

\begin{tabular}{|c|c|c|c|c|c|c|c|c|c|c|c|c|c|}
\hline $\begin{array}{c}\text { Device } \\
\text { code }\end{array}$ & $\bar{X}$ & Variance & $S D$ & 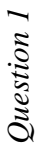 & 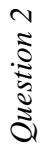 & 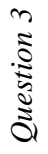 & 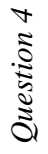 & 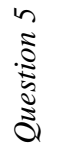 & 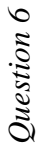 & 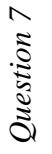 & 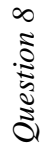 & 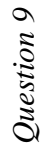 & $\underset{\Xi}{0}$ \\
\hline a1 & 36,63 & 296,52 & 17,22 & 1 & & & & 1 & & & & & 2 \\
\hline a3 & 52,23 & 267,39 & 16,35 & & & & 1 & 1 & & & 1 & 1 & 4 \\
\hline $\mathrm{a} 4$ & 38,06 & 332,73 & 18,24 & & 1 & & 1 & & & & 1 & & 3 \\
\hline a5 & 60,05 & 443,82 & 21,07 & 1 & 1 & 1 & 1 & 1 & 1 & 1 & 1 & 1 & 9 \\
\hline a6 & 31,42 & 674,08 & 25,96 & & 1 & & 1 & & 1 & & & & 3 \\
\hline a7 & 45,39 & 232,46 & 15,25 & & 1 & & 1 & & & & 1 & & 3 \\
\hline b1 & 41,67 & 235,09 & 15,33 & & 1 & & 1 & & & & 1 & & 3 \\
\hline b2 & 39,41 & 216,63 & 14,72 & & & & & 1 & & 1 & 1 & & 3 \\
\hline b3 & 37,50 & 303,54 & 17,42 & & & & & & & 1 & 1 & & 2 \\
\hline b4 & 45,39 & 178,75 & 13,37 & 1 & & & & & & & & & 1 \\
\hline b5 & 39,85 & 380,13 & 19,50 & & 1 & & & & & & & & 1 \\
\hline b6 & 47,50 & 346,07 & 18,60 & 1 & & 1 & & & & & & & 2 \\
\hline b7 & 39,66 & 287,54 & 16,96 & 1 & & & & & & & 1 & 1 & 3 \\
\hline c1 & 52,68 & 196,97 & 14,03 & & 1 & & 1 & 1 & & & 1 & 1 & 5 \\
\hline$\sum \bar{X}$ & 43,39 & & & & & & & & & & & & \\
\hline
\end{tabular}

The results presented in Table 1 suggest that attention level averages were low for seven students (those with device codes a1, a4, a6, b2, b3, b5, and b7). According to the eSense metric, these values were below normal attention levels. This could be explained by the finding that "Attention levels drop in states of excitement", as quoted in the eSense metric: when the video recordings were viewed, those students seemed to hesitate when participating. The video recordings of the students with normal attention levels, however, showed that they were more confident.

\section{Findings about Research Question Two}

The second research problem in the study was "Is there a significant relationship between the students" attention levels during class participation and their class participation rates?' For this problem, the previously found attention level averages were compared with the students' participation rates. The Pearson Correlation Coefficient calculated is presented in Table 2. 
Table 2

The Pearson correlation coefficient for the link between students' attention levels during questions and answers and the class participation rates

\begin{tabular}{llcc}
\hline & & $(1)$ & $(2)$ \\
\hline Attention level (1) & Pearson Correlation & 1 &, $699\left(^{* *}\right)$ \\
& Sig. (2-tailed) & &, 005 \\
& $\mathrm{~N}$ & 14 & 14 \\
$\begin{array}{l}\text { The number of } \\
\text { participating } \\
\text { students (2) }\end{array}$ & Pearson Correlation &, $699\left(^{* *}\right)$ & 1 \\
& & & \\
& Sig. (2-tailed) &, 005 & 14 \\
\hline
\end{tabular}

The analysis results presented in Table 2 suggest a moderate, positive correlation between the students' attention levels during class participation and the participation rates. This finding could be interpreted as increased attention levels in students leading to increased active participation. Conversly, it could also be argued that increased active participation leads to increased attention levels.

On the other hand, the regime distribution graph of the students' attention levels during class participation is presented in Graph 1:

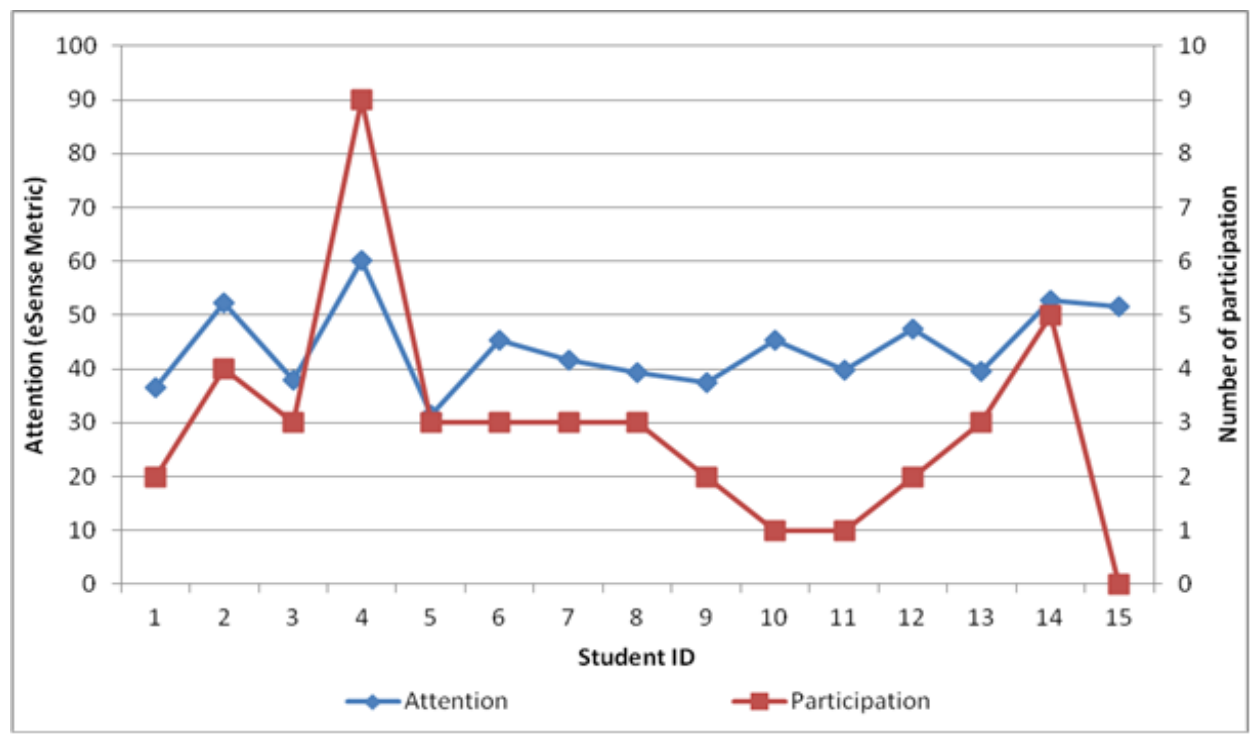

Graph 1

Distribution between class participation and attention levels 
The graph suggests that the students coded 1, 3, 5, and 9 had attention levels a little under the normal range described in the eSense metric. Taking into account the fact that the same students also participated in the class, this could be caused by excitement, as explained in the eSense metric.

\section{DISCUSSION AND CONCLUSION}

This research studied students' attention levels during class participation. In order to encourage participation, nine geography questions were put to the students and answers were received. The students' attention levels were examined when they answered the questions, in other words, when they participated in the class. Despite the low number of students, those with higher class participation rates were found to have higher-thanaverage attention levels throughout the class. The correlation analysis results also point to a significant positive link between the students' class participation and their attention levels. The research findings could therefore be presented as evidence corroborating the assumption in the literature that students participating in class have higher attention levels (Fidan, 1996; Schunk, 2008).

Steinert \& Snell (1999) put forward that students participated effectively in interactive lessons that involving techniques such as asking a question, questioning, brainstorming, small group study, and rhetorical questions. For them, the use of interactive lecturing can promote active learning, heighten attention and motivation, and give feedback to the teacher and the student in the lecture process. At this point, we note that students' attention decreases at first when any question are asked to students (İnel, 2014; Sezer, İnel, Seçkin \& Uluçınar, 2015). The value of interactive lecturing rests on the premise that active participation and involvement are a prerequisite for learning beyond the recall of facts, and that students must be attentive and motivated in order for learning to occur. Knox (1986) pointed out that questioning the audience is probably one of the most frequently used interactive techniques. Questions can trigger students' interest, arouse attention, operate as an 'ice breaker', and provide valuable feedback to the teacher and student alike. As discussed above, the act of asking a question has a moderator role enabling students to participate in class and enhancing students' attention in the learning process. Students increase their attention as well as participating in the lesson. Although the researchers have not encountered any study measuring quantitatively the relationship between students' attention and class participation in real classrooms, it is possible to say that the discussion based on relevant literature supports the findings revealed in this study.

Based on these findings, it could be proposed to create learning settings with more focus on teaching strategies, approaches, and methods that would enable students to participate more actively in the process of learning and teaching from the cognitive, affective, and behavioural aspects: in a process where students structure their knowledge and link their old knowledge with new and daily knowledge through active class participation, they will be more cognitively focused on the class. 


\section{REFERENCES}

Ames, C. (1992). Classrooms: Goals, structures, and student motivation. Journal of Educational Psychology, 84(3), 261-271.

Aypay, A. \& Eryılmaz, A. ( 2011). Lise öğrencilerinin derse katılmaya motive olmaları ile okul tükenmişliği arasındaki ilişkinin incelenmesi. Mehmet Akif Ersoy Üniversitesi Eğitim Fakültesi Dergisi, 21, 26-44.

Bacanl, H. (2002). Gelişim ve ögrenme. Ankara: Nobel Yayınevi.

Barkley, R. A. (2008). Classroom accommodations for children with ADHD. http://www.russellbarkley.org/factsheets/ADHD_School_Accommodations.pdf adresinden 12.02.2014 tarihinde erişilmiştir.

Bilen, M. (2006). Plandan uygulamaya ögretim. Ankara: Anı Yayıncılık.

Bomia, L., Beluzo, L., Demeester, D., Elander, K., Johnson, M. \& Sheldon, B. (1997). The impact of teaching strategies on intrinsic motivation. Champaign, IL: ERIC Clearinghouse on Elementary and Early Childhood Education. (ED 418 925).

Büyüköztürk, V., Çakmak, E. K., Akgün, Ö. E., Karadeniz, Ş. \& Demirel, F. (2012). Bilimsel araştırma yöntemleri. Ankara: Pegem Akademi.

Corkum, P., McGonnell, M. \& Schachar, R. (2010). Factors affecting academic achievement in children with ADHD. Journal of Applied Research on Learning, 3(9), 114.

Creswell, J. W. \& Plano - Clark, V. L. (2014). Karma yöntem araşttrmaları tasarımı ve yürütülmesi. (Y. Dede ve S. B. Demir Çev. Ed.). Ankara: Anı Yayıncılık.

Crowley, K., Sliney, A. Pitt, I. \& Murphy, D. (2010). Evaluating a brain-computer interface to categorise human emotional response. 10th IEEE International Conference on Advanced Learning Technologies. Sousse, Tunus.

Demirova, G. (2008). Piyano eğitiminin ilköğretim öğrencilerinin dikkat toplama yetisine etkisi. Mehmet Akif Üniversitesi Eğitim Fakültesi Dergisi, 8(16), 58 - 69.

Driscoll, M. P. (2012). Öğretim süreçleri ve öğrenme psikolojisi (Ö. F. Tutkun, S. Okay ve E. Şahin, Çev.). Ankara: Anı.

Erkuş, A. (2011). Davranış bilimleri için bilimsel araştırma süreci. Ankara: Seçkin Yayıncilik.

Eryılmaz, A. (2014). Üniversite öğrencileri için derse katılım ölçeklerinin geliştirilmesi. Uşak Üniversitesi Sosyal Bilimler Dergisi, 7(2): 203 - 2014.

Eryılmaz, A. \& Aypay, A. (2011). Ergenlerin derse katılmaya motive olmaları ile öznel iyi oluşları arasındaki ilişkinin incelenmesi. Uluslararası İnsan Bilimleri Dergisi, 8(1), $1219-1233$.

Fidan, N. (1996). Eğitim psikolojisi: Okulda ögrenme ve ögretme. Ankara: Alkım. 
İnel, Y. (2014). Sosyal bilgiler öğretiminde kullanılan bilgisayar temelli materyallerin 6. sınıf öğrencilerinin dikkat ve motivasyon düzeylerine etkisi (Unpublished doctoral dissertation), Gazi Üniversitesi Eğitim Bilimleri Enstitüsü, Ankara.

Kayan-Fadlelmula, F. (2010). Educational motivation and students' achievement goal orientations. Procedia Social and Behavioral Sciences, 2, 859-863.

Knox, A.B. (1986). Helping adults learn. San Francisco: Jossey-Bass.

Massoro, D. \& Cowan, N. (1993). Information processing models: Microscopos of the mind. Annual Review of Psychology, 44, 383-395.

McNamara, D. (1994). Classroom pedagogy and primary practice. London and New York: Routledge.

MindWave User Guide. (2009). Acessed: 02.04.2014, http://developer.neurosky.com/docs/lib/exe/fetch.php?media=mindwave_user_guide_en. pdf.

Morgan, C. T. (2011). Psikolojiye giriş (S. Karakaş ve R. Eski Çev. Ed.). Konya: Eğitim Kitabevi.

Neuman, W. L. (2009). Toplumsal araştırma yöntemleri: Nitel ve nicel yaklaşımlar (Sedef Özge, Çev.). İstanbul: Yayınodası.

Pintrich, P. R. \& De Groot, V. (1990). Motivational and self-regulated learning components of classroom academic performance. Journal of Educational Psychology, 82(1), 33-40.

Price, A., Crawford, S., Tottle, J. \& Maunula, S. (2006). Focusing on success teaching students with Attention Deficit/Hyperactivity Disorder. Alberta: Alberta Education.

Rabiner, D. L., Murray, D. W., Skinner, A. T. \& Malone, P. S. (2010). A randomized trial of two promising computer-based interventions for students with attention difficulties. J Abnorm Child Psychol, 38, 131-142.

Rebolledo-Mendes, G., Dunwell, I., Martvnes-Miron, E. A., Vargas-Cerdan, M. D., de Freitas, S., Liarokapis, F. \& Garcva-Gaona, A. R. (2009). Assessing NeuroSky's usability to detect attention levels in an assessment exercise. Proc. of the 13th International Conference on Human-Computer Interaction, Springer Berlin/Heidelberg Lecture Notes In Computer Science, Volume 5610/2009, San Diego, California, USA, 19-24 July, 149-158.

Salabun, W. (2014). Processing and spectral analysis of the raw EEG signal from the MindWave. doi:10.12915/pe.2014.02.44.

Schmidt, M. E. \& Vandewater, E. A. (2008). Media and attention, cognition, and school achievement. The Future of Children, 18(1), 63-85. 
Schunk, D. H. (2008). Learning theories: An educational perspective. New Jersey: Pearson Education.

Scott, D. \& Usher, R. (1999). Researching education data, methods and theory in educational enquiry. Eastbourne: CPI Antony Rowe.

Senemoğlu, N. (2005). Gelişim, öğrenme ve ögretim: Kuramdan uygulamaya. Ankara: Gazi.

Sezer, A., İnel, Y., Seçkin, A. Ç. \& Uluçınar, U. (2015). An investigation of university students' attention levels in real classroom settings with neurosky's mindwave mobile (EEG) device. International Educational Technology Conference, İstanbul, Turkey, 2729 May, $88-101$.

Sönmez, V. \& Alacapınar, F. G. (2011). Örneklendirilmiş bilimsel araştırma yöntemleri. Ankara: Anı.

Steinert, Y. \& Snell, L. S. (1999). Interactive lecturing: strategies for increasing participation in large group presentations. Medical Teacher, 21(1), 37-42.

Stewart, R. A., Rule, A. C. \& Giordano, D. A. (2007). The effect of fine motor skill activities on kindergarten student attention. Early childhood journal, 35(2), 103-109.

Sümbüloğlu, K. \& Sümbüloğlu, V. (2007). Biyoistatistik. Ankara: Hatiboğlu.

Tabachnick, B. G. \& Fidell, L. S. (2015). Çok değişkenli istatistiklerin kullanımı (M. Baloğlu, Çev. Ed.). Ankara: Nobel Yayınevi.

Tahiroğlu, A.Y., Çelik, G.G., Seydaoğlu, G., Uzel, M. \& Altunbaş, H. (2010). Shortterm effects of playing computer games on attention. J. Atten Disord, 13(6), 668-676.

Tuncer, M., Bal, S., Özüt, A. \& Köse, N. (2012). Ortaöğretim kurumları öğrenme ortamlarının çeşitli değişkenler açısından değerlendirilmesi. Gaziantep Üniversitesi Sosyal Bilimler Dergisi, 11(1), 85-101.

Wiersma, W. (1985). Research methods in education. Massachusetts: Allyn and Bacon, Inc. 


\section{Turkish Abstract \\ Sınıf Öğretmeniliği Bölümü Birinci Sınıf Öğrencilerinin Dikkat Seviyeleri ve Sınıf Katılımları Arasındaki İlişki}

Bu çalışma, sınıf öğretmeni adaylarının sınıf katılımlarıyla dikkat seviyeleri arasındaki ilişkiyi ortaya çıkarmayı amaçlamaktadır. Araştırma yöntemi olarak nicel nitel araştırma tekniklerini karma olarak ele alan yakınsak paralel dizayn kullanılmış ve çalışma grubu 2014-2015 akademik yılı güz döneminde Uşak Üniversitesi Eğitim Fakültesi Sınıf Öğretmenliği Bölümü'nden seçilmiş 21 birinci sınıf öğrencisinden oluşmaktadır. Veri toplama aracı olarak, öğrencilerin dikkat seviyelerini ölçmek için NeuroSky's Mindset EEG cihazı; sınıf katılımlarını belirlemek için de video kayıtları kullanılmıştır. Elde edilen veriler PYTHON ve MATLAB paket programları kullanılarak analiz edilmiştir. ESense ölçümüne göre bulgular öğrencilerin dikkat seviyelerinin belli bir ortalama düzeyde (43) olduğunu göstermiştir. Bu çalışma öğrencilerin sınıf katılımları ve dikkat seviyeleri arasında pozitif yönde bir ilişki olduğunu göstermektedir.

Anahtar Kelimeler: dikkat seviyesi, sınıf katılımı, NeuroSky's MindWave Mindset (EEG), sinıf öğretmeni adayları

\section{French Abstract \\ La Relation entre Niveaux d'Attention et Participation de Classe à Étudiants de Première année dans Départements d'Enseignement de Salle de classe}

Cette étude a eu pour but de détecter n'importe quelle relation qui peut exister entre les candidats de professeur de salle de classe la participation de classe et leurs niveaux d'attention. La méthode de recherche était un design(une conception) parallèle convergent, mélangeant des techniques de recherche quantitatives et qualitatives et le groupe d'étude a été composé de 21 étudiants de première année étudiant dans le Département d'Enseignement de Salle de classe à l'Université Usak, la Faculté d'Enseignement(Éducation), dans le premier trimestre du 2014-2015 an universitaire. Comme un instrument de collecte de données, l'équipement d'EEG de Mentalité de NeuroSky a été utilisé pour détecter les niveaux d'attention des étudiants, avec l'enregistrement en vidéo étant utilisé pour détecter leur participation de classe. Les données obtenues ont été analysées utilisant le PYTHON et les programmes de paquet MATLAB. Les découvertes ont montré que, selon l'eSense métrique, l'attention de niveau des étudiants était moyennement naturelle (43) comme il a été exposé. L'étude a conclu qu'a là existé une corrélation modérée, positive entre les niveaux d'attention des étudiants et la participation de classe.

Mots Clés: niveau d'attention, participation de classe, la Mentalité de NeuroSky MindWave (EEG), candidats de professeur de salle de classe 


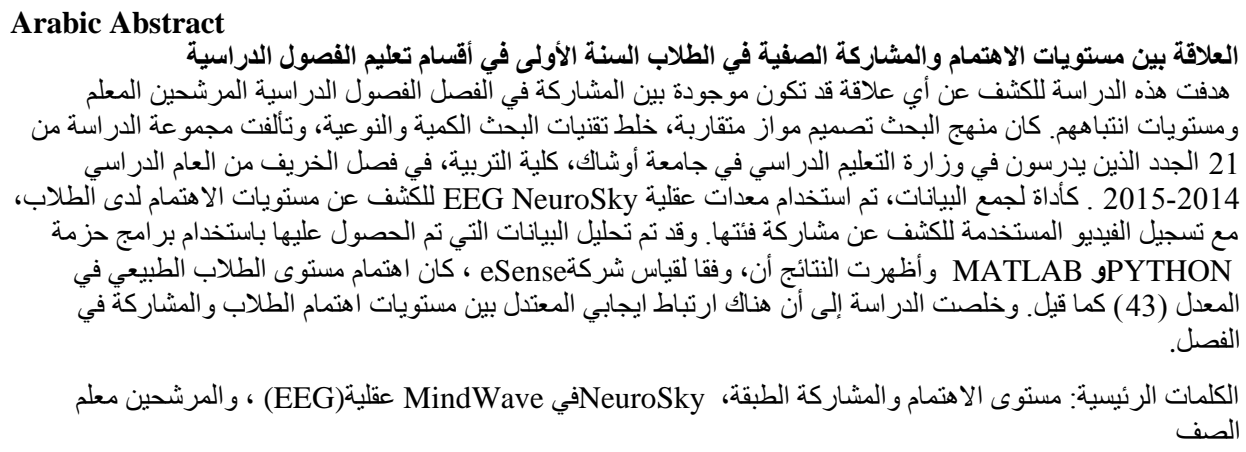

\section{German Abstract}

Die Beziehung zwischen Aufmerksamkeitsstufen und Klassenbeteiligung an Erststudenten im Grundschulunterricht

Diese Studie zielte darauf ab, jede Beziehung zu erkennen, die zwischen der GrundschullehrerKandidaten-Klassenbeteiligung und ihren Aufmerksamkeitsniveaus bestehen kann. Die Forschungsmethode war ein konvergentes Paralleldesign, das die quantitativen und qualitativen Forschungstechniken mischte, und die Studiengruppe bestand aus 21 Neulingen, die in der Primarschullehrerabteilung an der Universität Uşak, Fakultät für Erziehungswissenschaften, im Herbststudium des Fachhochschulabschlusses 2014-2015 studierten Jahr. Als Datenerfassungsinstrument wurde NeuroSky's Mindset EEG-Gerät verwendet, um die Aufmerksamkeit der Schüler zu erkennen, wobei die Videoaufzeichnung zur Erfassung ihrer Klassenbeteiligung verwendet wurde. Die erhaltenen Daten wurden mit den PYTHON- und MATLAB-Paketprogrammen analysiert. Die Ergebnisse zeigten, dass nach der eSense-Metrik die Aufmerksamkeit der SchülerInnen im Durchschnitt natürlich (43) war, wie es festgestellt wurde. Die Studie kam zu dem Schluss, dass es eine moderate, positive Korrelation zwischen den Aufmerksamkeit der Schüler und Klassenbeteiligung gab.

Schlüsselwörter: aufmerksamkeitsniveau, klassenbeteiligung, neuroskys mindwave mindset (eeg), grundschullehrerkandidaten 


\section{Malaysian Abstract \\ Hubungan antara Tahap Perhatian dan Penyertaan Kelas dalam pelajar tahun pertama di Jabatan Pengajaran}

Kajian ini bertujuan untuk mengesan apa-apa hubungan yang wujud penyertaan antara kelas dan tahap perhatian mereka. Kaedah penyelidikan adalah reka bentuk selari turtumpu, mencampurkan teknik penyelidikan kuantitatif dan kualitatif, dan kumpulan kajian adalah terdiri daripada 21 mahasiswa yang menuntut di Jabatan Pengajaran Bilik Darjah di Uşak University, Fakulti Pendidikan, dalam jangka musim luruh 2014-2015 tahun akademik. Sebagai instrumen pengumpulan data, peralatan Mindset EEG NeuroSky telah digunakan untuk mengesan tahap minat pelajar, dengan rakaman video yang digunakan untuk mengesan penyertaan kelas mereka. Data yang diperoleh dianalisis dengan menggunakan program PYTHON dan pakej MATLAB. Dapatan kajian menunjukkan bahawa, menurut metrik eSense, perhatian tahap pelajar adalah averagely asli kerana ia telah dinyatakan. Kajian ini menyimpulkan bahawa wujud, korelasi positif yang sederhana antara tahap perhatian pelajar dan penyertaan kelas.

Kata Kunci: Tahap perhatian, penyertaan kelas, NeuroSky ini MindWave Mindset (EEG), caloncalon guru kelas

\section{Russian Abstract \\ Взаимосвязь Между Внимание Уровней и Участия Класса в Первокурсники в Классе Преподавание Департаментов}

Это исследование проводилось с целью обнаружения каких-либо отношений, которые могут существовать между классным учителем и его учениками и уровнем их взаимопонимания. Метод исследования был сходящимся параллельный дизайн, использовалась смесь количественных и качественных методов исследования. Опытная группа состояла из 21 первокурсника педагогического факультета в университете Ушак. Исследование проводилось в осенний семестр 2014-2015 учебного года. В качестве инструмента сбора данных, настрой EEG оборудование NeuroSky использовался для определения уровней внимания студентов, видеозаписи использовались для мониторинга взаимоотношений в классе. Полученные данные были проанализированы с использованием программного пакета Python и MATLAB. Полученные данные показали, что, в соответствии с метрикой пакет ESense, уровень внимания студентов был средний (43) как это было сказано. В ходе исследования можно сделать вывод, что существует умеренная, положительная корреляция между уровнями внимания учащихся и их участием в занятиях.

Ключевые Слова: уровень внимания, класс участия, NeuroSky's MindWave Mindset (EEG), кандидаты классный руководитель 